\title{
Changes in plasma lipaemia, glycaemia and uremia caused by the negative interaction of the genotype and environment during the laying period of hens of initial lines of laying hybrids*
}

\section{Summary}

During the laying period the changes in concentrations of plasma total lipids, cholesterol, glucose and urea were studied in the RIW laying line selected for the number of eggs laid during the eight month laying period. The feed mixtures were changed qualitatively causing both changes in plasma lipaemia, glycaemia and uremia and time-limited reduction in the body weight and laying intensity. Average concentrations of the individual blood indicators of the entire group of hens during the laying period ranged as follows: total lipids $5.06 \pm 0.63 \mathrm{~g} .1^{-1}$ to $21.51 \pm 5.28 \mathrm{~g} . \mathrm{l}^{-1}$, cholesterol $1.99 \pm 0.45 \mathrm{mmol} .1^{-1}$ to $4.73 \pm 1.54 \mathrm{mmol} . \mathrm{1}^{-1}$, glucose $4.43 \pm 0.51 \mathrm{mmol}^{-1} \mathrm{1}^{-1}$ to $19.02 \pm 5.25$ mmol. $1^{-1}$ and urea $3.53 \pm 0.98 \mathrm{mmol} .1^{-1}$ to $6.29 \pm 2.51 \mathrm{mmol} .1^{-1}$.

The concentrations of the given biochemical indicators were also studied to contrast at the age of 25 weeks in other lines of hens originating from the RIW and BPR lines. The average values of all the studied indicators were different in lines of different laying intensity and earliness (fed the same feed mixture in the same hall), i.e. total lipids $25.00 \pm 7.51$ to $45.85 \pm 11.98{\mathrm{~g} .1^{-1}}^{-1}$, cholesterol $3.25 \pm 0.85$ to $4.83 \pm 0.81 \mathrm{mmol}^{-1}{ }^{-1}$, glucose $11.91 \pm 2.69$ to $15.15 \pm 1.98 \mathrm{mmol}^{-1}$ and urea $3.08 \pm 0.53$ to $6.90 \pm 1.61 \mathrm{mmol} .1^{-1}$.

We can say that during the laying period important changes in plasma lipaemia, glycaemia and uremia of the hens occur in dependence on changes in the feed mixture or in its quality too. These criteria monitor the level of interaction between the genotype and the environment on the level of pre-clinical response of the organism.

Key Words: laying hen lines, total lipids, cholesterol, glucose, urea, body weight, interactions

\section{Zusammenfassung}

Titel der Arbeit: Änderungen der Blutplasmalipemie, -glykemie und -harnstoff als Folge der Interaktion zwischen Genotypen und Milieu während der Legeperiode bei Hennen von Legelinien

Bei Hennen von Legelinien, die sich durch hohe Legeleistungen auszeichnen, wurden während der Legeperiode in Monatsintervallen die Gesamtlipid-(Glk), Cholesterin-(Ck), Glukose-(Gk) und Harnstoffkonzentrationen (Uk) im Blutplasma ermittelt. Einer in der 27. Lebenswoche erfolgten Erhöhung des Maisanteils zu ungunsten des Weizenanteils im Mischfutter folgte eine Veränderung in der Konzentration der untersuchten Blutparameter verbunden mit zeitbegrenzter Senkung des Korpergewichtes und der Legeleistung. Die Durchschnittswerte der Blutindikatoren schwankten wăhrend der Versuchsdauer bei Glk von $5,06 \pm 0.63 \mathrm{~g} .1^{-1}$, Ck von 1,99 $\pm 0,45$ bis $4,73 \pm 1,54$ mmol. $1^{-1}$, Gk von $4,43 \pm 0,51$ bis $19,02 \pm 5,25$ mmol. $\mathrm{I}^{-1}$, Uk von $3,53 \pm 098$ bis $6,29+2,5 \mathrm{mmol}^{-1}$. Diese Werte unterschieden sich bei gleichem Futterungsregime zwischen den Hennen der einzelnen Linien und schwankten z. B. bei Glk von $25,00 \pm 7,52$ bis $45,85 \pm 11,98 \mathrm{~g} \cdot 1^{-1}$, Ck von $3,25 \pm 0,85$ bis $4,83 \pm 0,81 \mathrm{mmol}^{-1} 1^{-1}$, Gl von $11,91 \pm 2,69$ bis $15,15 \pm 1,98 \mathrm{mmol}^{-1}$, Uk von $3,08 \pm 0,53$ bis $6,90 \pm 1,61 \mathrm{mmol} \cdot \mathrm{1}^{-1}$. Es ist festzustellen, daß während der Legeperiode in Abhängigkeit vom Genotyp sich die untersuchten Blutparameter aus der Sicht der Futterqualităt als Umweltindikatoren eignen.

Schlüsselwörter: Legehennenlinien, Gesamtlipide, Cholesterol, Glukose, Harnstoff, Körpergewicht, Interaktionen

\section{Introduction}

Sexual maturity in hens of the domestic fowl is accompanied with hyperlipaemia of the blood plasma because it is required for growth and reproduction. SALAGEANU 
(1989) stated that the concentration of total lipids and cholesterol in the blood of hens is the highest at the beginning of the laying period $\left(470.8\right.$ and $74.34 \mathrm{mg} .100 \mathrm{ml}^{-1}$, respectively). These values gradually decreased to 439.5 and $128.83 \mathrm{mg} .100 \mathrm{ml}^{-1}$, respectively, at the age of 360 days and to 343.63 and $132.58 \mathrm{mg} .100 \mathrm{ml}^{-1}$, respectively, at the age of 540 days. Similarly, NASR-EL-DIN et al. (1988) found that the concentrations of plasma total lipids and proteins were the highest before the onset of laying, but at the same time they drew attention to the fact that the concentration of glucose was lower. EL SAYED and BRACKENBURY (1988) found that the concentration of triglycerids in hen plasma as compared with female chickens and cocks was threefold higher. On the contrary, CEROLINI et al. (1990) reported a lower plasma lipemia at the age of 18 weeks, its rapid increase at 30 weeks of age and gradual increase up to the 67th week of age. MÁCHAL et al. (1994) studied the concentration of total lipids and cholesterol in blood plasma and egg yolk of hens of commercial laying lines and their relationship to hatchability and egg production.

During three weeks of investigations of the domestic fowl HALL and McKAY (1994) found only small changes in plasma cholesterol concentrations. When rearing quail PEEBLES et al. (1996) observed a relatively high variability in the concentration of cholesterol and glucose in the blood serum, and a lower in the concentration of triglycerids.

CUNNINGHAM et al. (1974) in hens and MARKS and WASHBURN (1991) in Japanese quail reported that plasma cholesterol concentrations of whole lines can be reduced by selection. CHRISTENSEN et al. (1993) voiced his opinion obtained on the basis of investigations of the reduction of glycogen in the liver of turkey embryos from lines selected for egg laying that intensively selected lines have a different metabolism. FURUSE et al. (1991), for instance, referred to the relationship of changes in the concentration of blood glucose and lipid metabolism. Several authors (SIM et al., 1980; KIM and HAN, 1985; JIANG et al., 1990; MARTINEZ et al., 1992; VAN ELSWYKl et al., 1994) reported that changes in the diet, and/or the application of special preparations, could influence blood lipaemia, glycaemia or cholesterol concentrations. KOVÁČ et al. (1991) confirmed that plasma cholesterol concentrations of laying hens were dependent on the content of metabolizable energy (ME) in the feed mixture which decrease with the content of ME.

The levels of plasma lipaemia and glycaemia change both during rearing and breeding at maturity and in dependence on the feed taken up, production efficiency, but also on any rapid change in the environment, e.g. MATE et al. (1996) stated increased plasma cholesterol concentration as a response to stress in hens.

\section{Materials and Methods}

For studies of the dynamics of changes in the concentration of selected biochemical indicators of blood (total lipids, cholesterol, glucose and urea) during the laying period we used 24 hens of the highly efficient maternal line RIW - 1 (RIW - 1a) selected for egg production which were housed in cages, i.e. two to each cage. The hens were brought to the laying hall at the age of 17 weeks. During the studied period (from the 
20 th to 57 th week of age) the experimental hens were given ad libitum standard feed mixture for breeding hens. The composition of this mixture was modified in the 26th week of age, i.e. the proportion of maize was increased from $30.0 \%$ to $50.5 \%$ and that of wheat was reduced from $33.8 \%$ to $13.8 \%$, the $\mathrm{N}$ substances were reduced from $192.30 \mathrm{~g}$ to $185.76 \mathrm{~g}$, in this way modifying the ratio of $\mathrm{N}$ substances: metabolizable energy. In order to find the dynamics of changes of the studied indicators blood of the hens was sampled from the vena cutanea ulnaris at the age of 20 weeks and then eight times more, always in monthly intervals. The last blood sampling was performed at the age of 57 weeks. Blood was always sampled between 8 and 10 a.m. The blood was then centrifuged to express the plasma, samples were analysed within 2 hours of collection. At every blood sampling each hen was weighed individually to record the body weight. The number of laid eggs was counted every day in the entire group and from it the weekly intensity of egg production was calculated and plotted into the laying curve; the monthly average egg production was calculated from the egg production during 16 days before and after blood sampling.

In order to compare the initial values of the selected biochemical blood indicators of hens of the studied line, blood was sampled at the age of 25 weeks not only from the RIW - 1a hens, but also from 60 other hens of three initial lines fed a modified feed mixture over the entire laying period ( 20 hens of line RIW - 1 (RIW - 1b) - sisters of hens of the same age of the line RIW - 1a, 20 hens of the line RIW - 2 and 20 hens of the inbred line BPR). The hens were placed individually in cages in another laying hall and fed ad libitum.

Bio-La assays were used for determinations of the contents of total plasma lipids, cholesterol, glucose and urea. Selected traits and the found values of blood markers were evaluated statistically. The correlations were defined using the calculated phenotypical correlations.

\section{Results}

The average values of concentrations of the selected biochemical blood indicators and average body weight, weekly and monthly egg production during the laying period are given in Table 1. The average concentration of total lipids in the blood plasma of the studied hens was found to be the highest at the beginning of the laying period, i.e. at the age of 20 and 25 weeks $\left(5.06 \pm 0.63\right.$ and $5.09 \pm 0.68$ g. $1^{-1}$, respectively), the maximal values were reached at 37 and 42 weeks of age $(24.51 \pm 5.28$ and $20.09 \pm$ $7.26 \mathrm{~g} .1^{-1}$, respectively). Cholesterol concentrations were similar, the lowest average concentration was found at 25 weeks of age $\left(1.99 \pm 0.45 \mathrm{mmol} .1^{-1}\right)$, the highest in the 37 th week $\left(4.73 \pm 1.54 \mathrm{mmol}^{-1} \mathrm{1}^{-1}\right)$. The course of glycaemia during the laying period was the same as the concentration of total lipids - the lowest average values were again found at the beginning of the laying period (20th week of age $4.44 \pm 0.51 \mathrm{mmol} .1^{-1}$ and 25 th week of age $4.87 \pm 0.37 \mathrm{mmol}^{-1}$ ). The average value of uremia was found to be the lowest at 25 weeks of age $\left(3.53 \pm 0.98 \mathrm{mmol}^{-1} \mathrm{1}^{-1}\right)$, the highest again at 37 weeks $\left(6.29 \pm 2.51 \mathrm{mmol}^{-1}\right)$. To a certain extent the course of average values of concentra- 
tions of blood indicators during the laying period corresponded with the body weight of the hens. The body weight of the hens was the lowest at 25 weeks of age $(1.71 \pm$ $0.14 \mathrm{~kg})$, the highest at 42 and 46 weeks $(1.85 \pm 0.20 \mathrm{~kg}$ and $1.85 \pm 0.21 \mathrm{~kg}$, respectively).

Table 1

Average values of concentrations of selected biochemical blood indicators and average body weight, weekly and monthly egg production and unifactorial variance analysis during the laying period-line RIW-1a (Durchschnittswerte ausgewählter biochemischer Blutindikatoren sowie durchschnittliches Körpergewicht, wöchenliche und monatliche Eiproduktion während der Legeperiode, varianzanalytisch ausgewertet)

\begin{tabular}{|c|c|c|c|c|c|c|c|c|}
\hline $\begin{array}{l}\begin{array}{c}\text { Age of } \\
\text { hens }\end{array} \\
\text { (weeks) }\end{array}$ & $\mathbf{n}$ & $\begin{array}{l}\text { Total } \\
\text { Lipids } \\
\left(\mathrm{g} . \mathrm{I}^{-1}\right)\end{array}$ & $\begin{array}{l}\text { Cholesterol } \\
\left(\mathrm{mmol} \mathrm{.} \mathrm{l}^{-1}\right)\end{array}$ & $\begin{array}{c}\text { Glucose } \\
\left(\mathrm{mmol} \mathrm{.} \mathrm{l}^{-1}\right)\end{array}$ & $\begin{array}{c}\text { Urea } \\
\left(\mathrm{mmol} . \mathrm{l}^{-1}\right)\end{array}$ & $\begin{array}{c}\text { Body } \\
\text { weight } \\
\text { (kg) }\end{array}$ & $\begin{array}{l}\text { Weekly } \\
\text { egg } \\
\text { production } \\
(\%)\end{array}$ & $\begin{array}{l}\text { monthly } \\
\text { egg } \\
\text { production } \\
(\%) \\
\end{array}$ \\
\hline 20 & 24 & $5.06 \pm 0.63$ & $3.54 \pm 0.56$ & $4.43 \pm 0.51$ & $3,70 \pm 0.70$ & $1.76 \pm 0.09$ & 33.2 & 27.9 \\
\hline 25 & 23 & $5.09 \pm 0.68$ & $1.99 \pm 0.45$ & $4.87 \pm 0.37$ & $3.53 \pm 0.98$ & $1.71 \pm 0.14$ & 83.3 & 88.2 \\
\hline 29 & 23 & $16.04 \pm 5.06$ & $3.01 \pm 0.81$ & $9.49 \pm 0.96$ & $4.82 \pm 1.52$ & $1.82 \pm 0.16$ & 93.5 & 93.9 \\
\hline 33 & 23 & $15.95 \pm 7.62$ & $3.04 \pm 0.59$ & $14.33 \pm 1.92$ & $5.24 \pm 2.02$ & $1.80 \pm 0.15$ & 94.4 & 91.6 \\
\hline 37 & 22 & $21.51 \pm 5.28$ & $4.73 \pm 1.54$ & $18.52 \pm 6.36$ & $6.29 \pm 2.51$ & $1.83 \pm 0.13$ & 88.3 & 89.0 \\
\hline 42 & 21 & $20.09 \pm 7.26$ & $3.30 \pm 0.72$ & $15.65 \pm 3.79$ & $5.14 \pm 2.10$ & $1.85 \pm 0.20$ & 87.8 & 85.5 \\
\hline 46 & 20 & $19.20 \pm 7.44$ & $2.93 \pm 0.87$ & $15.77 \pm 2.55$ & $4.97 \pm 1.66$ & $1.85 \pm 0.21$ & 81.4 & 81.1 \\
\hline 52 & 20 & $17.19 \pm 8.10$ & $3.50 \pm 0.76$ & $19.02 \pm 5.25$ & $5.55 \pm 2.66$ & $1.83 \pm 0.17$ & 82.9 & 80.3 \\
\hline 57 & 19 & $13.83 \pm 8.80$ & $2.59 \pm 0.65$ & $12.42 \pm 2.24$ & $3.89 \pm 1.86$ & $1.77 \pm 0.20$ & 69.5 & 66.3 \\
\hline $\begin{array}{c}\text { Calculated } \\
\text { values F }\end{array}$ & & $18.67^{++}$ & $15.70^{++}$ & $67.12^{++}$ & $5.39^{++}$ & $\cdots$ & $\ldots$ & $\ldots$ \\
\hline
\end{tabular}

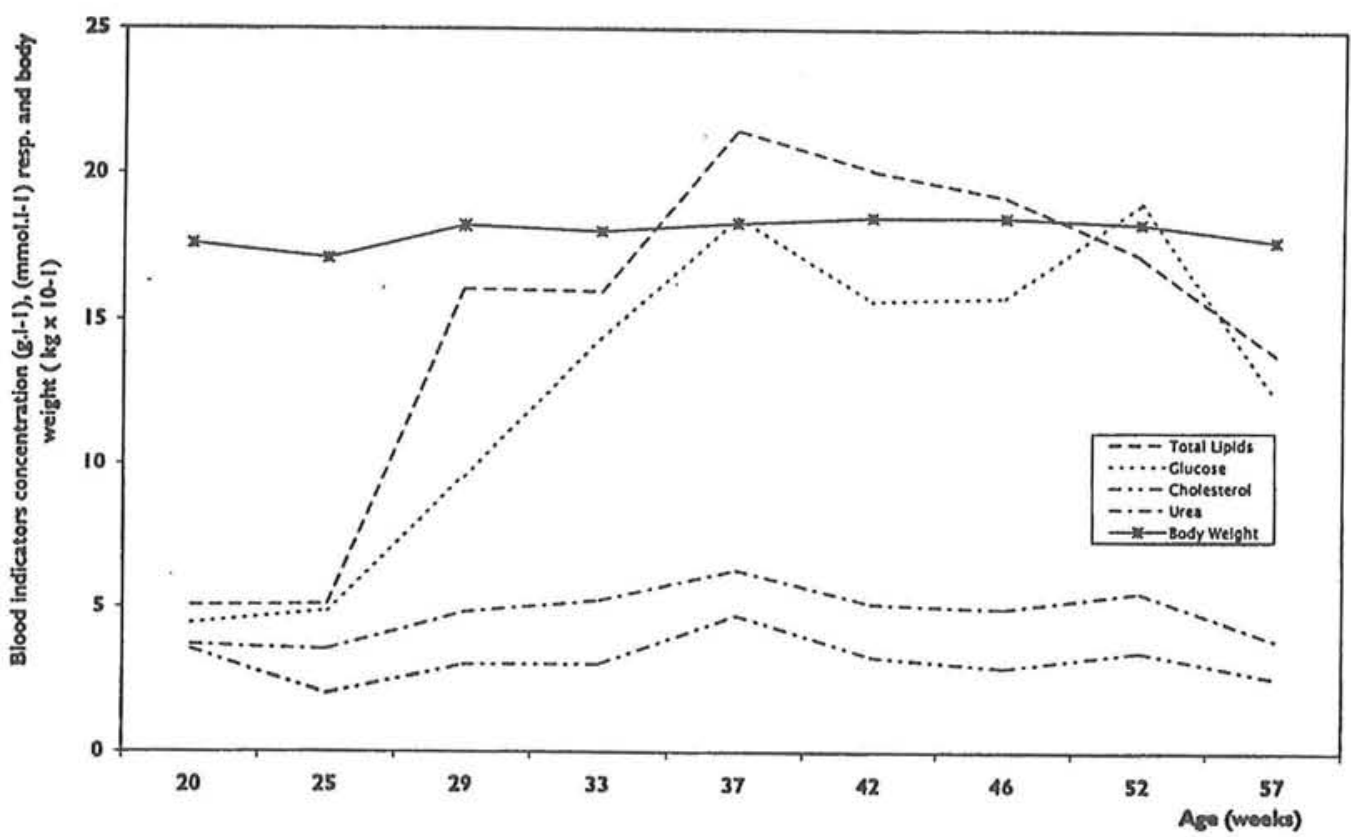

Fig. 1: Biochemical blood indicators and body weight in the hens during the laying period (RIW-1a) (Biochemische Blutindikatoren und Korpergewicht bei den Hennen wahrend der Legeperiode) 
Arch. Tierz. 43 (2000) 1

During the laying period the average values of all the studied indicators changed highly significantly, i.e. $\mathrm{P} \leq 0.01$. Figure 1 gives the dynamics of the given criteria.

Table 2

Average values of concentrations of plasma total lipids, cholesterol, glucose and urea in hens of the lines RIW - 1a, RIW - 1b, RIW - 2 and BPR at the age of 25 weeks (Durchschnittswerte der Gesamtlipidkonzentration, der Cholesterin-, Glukose- und Harnstoffkonzentration bei Hennen verschiedener Linien im Alter von 25 Wochen)

\begin{tabular}{|c|c|c|c|c|c|}
\hline Line & $\mathbf{n}$ & $\begin{array}{c}\text { Total Lipids } \\
\left(\mathrm{g} \cdot \mathrm{I}^{-1}\right)\end{array}$ & $\begin{array}{c}\text { Cholesterol } \\
\left(\mathrm{mmol} .^{-1}\right)\end{array}$ & $\begin{array}{c}\text { Glucose } \\
\left(\mathrm{mmol.} \mathrm{I}^{-1}\right)\end{array}$ & $\begin{array}{c}\text { Urea } \\
\left(\mathrm{mmol} . \mathrm{I}^{-1}\right)\end{array}$ \\
\hline RIW - la & 23 & $\begin{array}{c}\mathrm{b}, \mathrm{c}, \mathrm{d} \\
5.09 \pm 0.68 \\
\mathrm{a}, \mathrm{b}\end{array}$ & $\begin{array}{c}\mathrm{b} \\
1.99 \pm 0.45\end{array}$ & $\begin{array}{c}\text { b,c,d } \\
4.87 \pm 0.37 \\
\text { b }\end{array}$ & $3,70 \pm 0.70$ \\
\hline RIW - $1 b$ & 20 & $\begin{array}{c}25.00 \pm 7.51 \\
\mathrm{c}\end{array}$ & $3.25 \pm 0.85$ & $\begin{array}{c}11.91 \pm 2.69 \\
\text { c }\end{array}$ & $\begin{array}{c}5.89 \pm 0.84 \\
\text { a }\end{array}$ \\
\hline RIW - 2 & 20 & $\begin{array}{c}31.57 \pm 6.24 \\
\text { a,d } \\
45.85 \pm 11.98\end{array}$ & $\begin{array}{c}3.64 \pm 1.10 \\
b \\
4.83 \pm 0.81\end{array}$ & $\begin{array}{c}13.57 \pm 0.85 \\
\mathrm{~d} \\
15.15 \pm 1.98\end{array}$ & $\begin{array}{c}3.08 \pm 0.53 \\
a \\
6.90 \pm 1.61\end{array}$ \\
\hline
\end{tabular}

a-significant $(P \leq 0.05) ; \quad b, c, d-$ significant $(P \leq 0.01)$



Fig. 2: Biochemical blood indicators in the hens of the laying lines $\left(25^{\text {th }}\right.$ week of age) (Biochemische Blutindikatoren bei Hennen aus Legelinien (25. Lebenswoche))

The concentrations of total lipids, cholesterol, glucose and urea in blood plasma of hens of various lines were determined at the age of 25 weeks in three lines to compare their initial values (Tab. 2). The highest average values of concentration of total lipids were found in hens of the BPR line $\left(45.85 \pm 11.98 \mathrm{~g} \cdot 1^{-1}\right)$, the lowest in RIW - 1a hens $\left(5.09 \pm 0.68\right.$ g. $\left.1^{-1}\right)$ (Fig. 2). The results were similar also in terms of cholesterol concentrations (BPR $4.83 \pm 0.81 \mathrm{mmol}^{-1} \mathrm{I}^{-1}$, RIW - 1a $1.99 \pm 0.45 \mathrm{mmol} . \mathrm{1}^{-1}$ ) and glu- 
cose concentrations (BPR $15.15 \pm 1.98 \mathrm{mmol}^{-1}$, RIW - 1a $4.87 \pm 0.37 \mathrm{mmol} . \mathrm{1}^{-1}$ ). Different results were found for blood urea concentrations where the highest average concentration was again found in the BPR hens $\left(6.90 \pm 1.61 \mathrm{mmol}^{-1}\right)$ but the lowest in the RIW - 2 line $\left(3.08 \pm 0.53 \mathrm{mmol}^{-1}\right)$.

\section{Discussion}

In the studied hens of the maternal line RIW - 1a a high variability was found of all the blood indicators during the laying period, the differences being highly significant. The most marked changes were in the average concentration of blood total lipids in the individual months of age $\left(5.06 \pm 0.63 \mathrm{~g} .1^{-1}\right.$ to $\left.21.51 \pm 5.28 \mathrm{~g} .1^{-1}\right)$, blood cholesterol - in contrast to the findings of HALL and MCKAY, $1994-\left(1.99 \pm 0.45 \mathrm{mmol}^{-1}\right.$ to $4.73 \pm$ $\left.1.54 \mathrm{mmol} . \mathrm{1}^{-1}\right)$ and blood glucose $\left(4.43 \pm 0.51 \mathrm{mmol} .1^{-1}\right.$ to $\left.19.02 \pm 5.25 \mathrm{mmol} . \mathrm{I}^{-1}\right)$. The range of the average values of urea concentrations was found to be somewhat lower, but even so it ranged between $3.53 \pm 0.98 \mathrm{mmol}^{-1}$ and $6.29 \pm 2.51 \mathrm{mmol} . \mathrm{1}^{-1}$. The values of lipaemia and glycaemia were found to be the lowest at the beginning of egg production at the age of 20 and 25 weeks. Not only is this situation atypical in terms of our earlier investigations but it is also at variance with data of other authors (SALAGEANU, 1989; NASR-EL-DIN et al., 1988; EL SAYED and BRACKENBURY, 1988). These results can be compared with the investigations of CEROLINI et al. (1990) who, in contrast with other authors, found a lower level of lipaemia in blood plasma at 18 weeks of age and its rapid increase up to 30 weeks of age. The values of blood lipaemia and uremia were found to be the highest at 37 weeks of age (total lipids $21.51 \pm 5.28 \mathrm{~g} . \mathrm{l}^{-1}$, cholesterol $4.73 \pm 1.54 \mathrm{mmol} . \mathrm{1}^{-1}$, urea $\left.6.29 \pm 2.51 \mathrm{mmol} . \mathrm{1}^{-1}\right)$. The same course of blood lipaemia was also found in cocks of the initial lines (MÁCHAL et al., 1996). As concerns glycaemia there were two peaks - at 37 weeks of age (18.52 $\left.\pm 6.36 \mathrm{mmol}^{-1} \mathrm{1}^{-1}\right)$ and at 52 weeks of age $\left(19.02 \pm 5.25 \mathrm{mmol} . \mathrm{1}^{-1}\right)$.

The course of lipaemia, glycaemia and uremia corresponds with the development of body weight of hens; in the week when energetic sources in blood plasma were the lowest (25th week) a non-physiological decrease in the average body weight occurred (from $1.76 \mathrm{~kg}$ to $1.71 \mathrm{~kg}$ ) and at the same time a temporary decrease in weekly egg production, i.e. from $92.3 \%$ to $83.3 \%$, what was again repeated to a smaller extent at 33 weeks of age and more strongly at the end of egg production at 56 weeks of age.

These reductions always occurred in association with changes in the quality of the feed mixture. If the hens at the beginning of the laying period were capable of supplying the energetic deficit from their own body reserves, in the 25th week of age this deficit markedly affected not only the blood plasma but also egg production and body weight. A positive turn occurred after the composition of the feed mixture was changed. In spite of this fact the two following unplanned fluctuations in the quality of the feed mixture caused a decrease not only in the concentration of lipaemia in the 33rd week of age but also of glycaemia and uremia in the 56th week.

When we compare the initial concentrations of lipaemia, glycaemia and uremia of various initial laying lines at 25 weeks of age, we can see that the average values in the individual indicators of line RIW - 1a, with deficit feeding, were below-the-limit, in 
contrast to their sisters fed a modified feed mixture. For instance, the average concentration of total lipids of the experimental hens of line RIW - 1a was only 5.09 \pm $0.68 \mathrm{~g} .1^{-1}$ while that of their sisters of the same age - RIW - 1b was $25.00 \pm 7.51 \mathrm{~g} .1^{-1}$. A similar difference was observed in the concentration of plasma cholesterol (1.99 \pm $0.45 \mathrm{mmol}^{-1}$ vs $3.25 \pm 0.85 \mathrm{mmol}^{-1}$ ), glucose $\left(4.87 \pm 0.37 \mathrm{mmol}^{-1} \mathrm{f}^{-1}\right.$ vs $11.91 \pm 2.69$ $\left.\mathrm{mmol} . \mathrm{1}^{-1}\right)$ and urea $\left(3.70 \pm 0.70 \mathrm{mmol} . \mathrm{1}^{-1}\right.$ vs $\left.5.89 \pm 0.84 \mathrm{mmol}^{-1}\right)$.

The great differences in the average values of lipaemia, glycaemia and uremia between the respective lines correspond with earlier investigations (MÁCHAL et al., 1994). A repeatedly confirmed fact are the high values of lipaemia (total lipids $45.85 \pm 11.98$ g. $1^{-1}$, cholesterol $\left.4.83 \pm 0.81 \mathrm{mmol}^{-1} \mathrm{1}^{-1}\right)$ and glycaemia $\left(15.15 \pm 1.98 \mathrm{mmol} . \mathrm{1}^{-1}\right)$ in the inbred line BPR with maturity delayed by ca 21 days followed by lower egg production.

It was found that during the laying period considerable changes occurred in plasma lipaemia, glycaemia and uremia of hens also in dependence on changes in the feed mixture or in its quality. These changes which indicate impaired conditions for the realisation of the genotype are accompanied by a reduced intensity of egg production in the high-producing lines and even by an undesirable decrease in body weight. At the same time the given criteria monitor the level of interaction of the genotype and the environment on the level of pre-clinical response of the organism.

\section{References}

CEROLINI, S.; BALDI, A.; CAVALCHINI, L.G.:

Blood and plasma biochemical variables in laying hens of different strains and ages. Arch. Geflugelkunde 54 (1990), 190-194

CHRISTENSEN, V.L.; DONALDSON, W.E.; NESTOR, K.E.:

Embryonic viability and metabolism in turkey lines selected for egg production or growth. Poultry Sci., 72 (1993), 829-838

CUNNINGHAM, D.L.; KRUEGER, W.F.; FANGUY, R.C.; PEABODY, J.W.:

Preliminary results of bidirectional selection for yolk cholesterol level in laying hens. Poultry Sci., 53 (1974), 384-391

HALL, L.M.; McKAY, J.C.:

Variation in plasma cholesterol concentration over time in the domestic fowl. Brit. Poultry Sci., 35 (1994), 631-634

EL SAYED, M.S.; BRACKENBURY, J.H.:

Sexual maturity and physical exercise alter fibrinolytic activity in bords (chickens). Comparative Biochemistry and Physiology, A comparative Physiology, 90 (1988), 409-411

FURUSE, M.Y.; ISHII, T.; MIYAGAWA, S.; NAKAGAWA, T.; SHIMIZU, T.; WATANABE, T.; OKUMURA, J.:

Effect of dietary sorbose on lipid metabolism in male and female broilers. Poultry Sci., 70 (1991), 95102

GRIMES, J.L.; MAURICE, D.V.; LIGHTSEY, S.F.; GAYLORD, T.G.: Dietary prilled fat and layer chicken performance and egg composition. Poultry Sci., 75 (1996), 250-253

JIANG, Z.; CHERIAN, G.; ROBINSON, F.; SIM, J.: Effect of feeding cholesterol to laying hens and chicks on cholesterol metabolism in pre- and posthatch chicks. Poultry Sci., 69 (1990), 1694-1701

KIM, K.N.; HAN, I.K.:

Effects of different dietary sources of cholesterol, protein and fiber on lipid metabolism in broiler chicks. Korean J. Anim. Sci., 27 (1985), 362-366 
KOVÁČ, M.; ANGELOVIČOVÁ, M.; KREDATUS, S.:

Effect of energy and wheat treated by chemical hydrolysis in mixed feeds for laying hens on cholesterol in blood serum and egg yolk. Polnohospodárstvo, 37 (1991), 489-496

MÁCHAL, L.; INGR, I.; KALOVÁ, J.; JEŘ̉́BEK, S.: The dependence of the hatchability, laying, and egg weight on the cholesterol level and cholesterol and total lipids concentration in the blood plasma in hens of laying strains. Arch. Tierz., Dummerstorf 37 (1994), 567-575

MÁCHAL, L.; KALOVÁ, J.; JURÁŇ, P.; JEŘ̉́BEK, S.:

The dynamics of the relationship between ejaculate quality and cholesterol and total lipids concentration in the blood plasma in two lines of the cocks. Arch. Tierz., Dummerstorf 39 (1996), 61-68

MATE, D.; TUREK, P.; NAGY, J.:

Effect of stress on the cholesterol level in the blood serum of laying hens and in egg yolk. Slovenský veterinárný èasopis, 21 (1996), 259-261

MARKS, H.L.; WASHBURN, K.W.:

Plasma and yolk cholesterol levels in Japanese quail divergently selected for plasma cholesterol response to adrenocorticotropin. Poultry Sci., 70 (1991), 429-433

MARTINEZ, V.M.; NEWMAN, R.K.; NEWMAN, C.W.:

Barley diets with different fat sources have hypocholesterolemic effects in chicks. J. Nutr. Bethesda, 122 (1992), 1070-1076

NASR - EL - DIN, R.A.; YOUSEF, A.A.; MAHMOUD, M.F.; IBRAHIM, I.A.:

Thyroid hormones, glucose, total lipids and total proteins in blood serum before and during laying in Hisex Brown chickens. J. Anim. Physiol. and Anim. Nutr., 59 (1988), 167-170 PEEBLES, E.D.; CHEANEY, J.D.; VAUGHN, K.M.; LATOUR, M.A.; SMITH, T.W.; HAYNES, R.L.;
BOYLE, C.R.:

Changes in gonadal weights, serum lipids, and glucose during maturation in the juvenile northern bobwhite quail. Poultry Sci., 75 (1996), 1411-1416

SALAGEANU, G.:oo

Blood lipid dynamics in fowls raised for eggs. Lucrari Stiintifice, Institutul Agronomic, Bucuresti, Seria C - Medicina Veterinara, 32 (1989), 33-39

SIM, J.S.; KITTS, W.D.; BRAGG, D.B.:

Effect of dietary egg yolk on serum cholesterol levels of White Leghorn Cockerels. Poultry Sci., 59 (1980), 1812-1817

VAN ELSWYK, M.E.; HARGIS, B.M.; WILLIAMS, J.D.; HARGIS, P.S.:

Dietary menhaden oil contributes to hepatic lipidosis in laying hens. Poultry Sci., 73 (1994), 653-662

\author{
Received: 15.01 .1999 \\ Accepted: 15.09 .1999 \\ Authors' addresses \\ doc.ing.LADISLAV MÁCHAL, CSc. \\ Mendel's Agricultural and Forestry University \\ Zeme̊dęlská 1 \\ 61300 Brno - Czech Republic \\ doc. ing. STANISLAV JEŘÁBEK, CSc. \\ Integra Žabčice a.s. \\ 66463 Žabxice - Czech Republic
}

